\title{
Infectious diseases in Mazzaella laminarioides (Rhodophyta): estimating the effect of infections on host reproductive potential
}

\author{
Sylvain Faugeron ${ }^{1,2}$, Enrique A. Martínez ${ }^{1}$, Pablo A. Sánchez ${ }^{1}$, Juan A. Correa ${ }^{1, *}$ \\ ${ }^{1}$ Departamento de Ecología, Facultad de Ciencias Biológicas, Pontificia Universidad Católica de Chile, Casilla 114-D, \\ Santiago, Chile \\ ${ }^{2}$ Laboratoire de Génétique et Evolution des Populations Végétales, UPRESA CNRS 8016, Université de Lille I, \\ 59655 Villeneuve d'Ascq Cedex, France
}

\begin{abstract}
Very little is known about the potential effects of endophytic infections on the host in algae, especially in terms of fitness. In this study, we report a first attempt at quantifying the effects of the endophytes Endophyton ramosum (Chlorophyta) and Pleurocapsa sp. (Cyanophyta) on the reproductive potential of their host Mazzaella laminarioides (Rhodophyta). Density of reproductive structures and spore germination rates was compared between infected and non-infected fronds. It was found that differences in density of reproductive structures between infected and non-infected fronds were not significant, which suggests that the level of maturity of the host is unaltered by the endophytes. On the other hand, carpospore germination rates significantly decreased when produced by fronds infected by the cyanobacterium Pleurocapsa sp. Thus, in the general context of host fitness, we discuss the fact that only some of the components of the reproductive output of M. laminarioides are negatively affected by the endophytes.
\end{abstract}

KEY WORDS: Cyanobacteria $\cdot$ Endophyton ramosum $\cdot$ Endophyte infections $\cdot$ Fitness $\cdot$ Mazzaella laminarioides $\cdot$ Pleurocapsa

Resale or republication not permitted without written consent of the publisher

\section{INTRODUCTION}

Most of the research on infectious diseases in algae has focused on characterizing the parasites and describing morphological aspects of host-parasite interactions at the cellular and tissue level (reviewed by Andrews 1976, Andrews \& Goff 1984, Correa 1997). Studies going beyond the description stage, particularly into the effect of infections on the host fitness components (i.e. reproduction and survival), are scarce. In red algae, for example, infections have been investigated in terms of the effect of the parasites on carbon fixation and growth rate in their host. Kremer (1983) showed that although there was carbon transfer from the host Rhodomela confervoides to its parasite Harveyella mirabilis, carbon fixed by the host was enough

${ }^{*}$ Corresponding author. E-mail: jcorrea@genes.bio.puc.cl to cover the needs of both the parasite and the host. Apt (1984) showed that infections by the red alga Hypneocolax stellaris reduced the growth rate of its host Hypnea musciformis by $40 \%$ in the field, and up to $70 \%$ in laboratory trials. Buschmann et al. (1997) showed that infected fronds of Mazzaella laminarioides were removed significantly faster by wave impact than were non-infected thalli. Other descriptive studies have reported a virus infecting specifically the reproductive structures in species of Ectocarpus (Müller et al. 1990, Müller \& Frenzer 1993, Parodi \& Müller 1994), and therefore capable of acting as a castrator. These observations and experiments suggest that parasites or pathogens could affect host survival or its reproductive potential-2 important parameters in the context of fitness.

In this study, we estimated the effect of 2 pathogenic infections on the reproduction of the host Mazzaella 
laminarioides (Bory) Fredericq (Gigartinales, Rhodophyta). This host is an ecologically and economically important species, abundant on the rocky intertidal zone along the coast of central and southern Chile. It is characterized by an alternation of isomorphic generations of lanceolate fronds issued from a perennial holdfast (Fig. 1a). The 2 infecting organisms are the cyanobacterium Pleurocapsa sp. and the filamentous green alga Endophyton ramosum Gardner (Fig. 1b,c). E. ramosum infects mainly the base of the fronds, where it causes tissue degradation and facilitates frond fracture (Fig. 1b,c; Correa et al. 1994), whereas Pleurocapsa sp. infects the entire frond, producing small but often numerous galls (Fig. 1d,e; Correa et al. 1993). Buschmann et al. (1997) suggested that tissue weakening by E. ramosum was the cause of a reduction in frond survival. In central Chile, 45 to $55 \%$ of the fronds have been recorded as infected by E. ramosum, compared to only 5 to $10 \%$ by Pleurocapsa sp. (Correa et al. 1997). It must be considered, however, that the latter pathogen displays a highly aggregated spatial distribution, with small areas of the beach having nearly all fronds heavily infected whereas the rest of the population remains uninfected (Correa \& Sánchez 1996). Furthermore, Correa \& Sánchez (1996) also suggested a potentially negative effect of the infections on host reproduction based on the observation that, in natural populations of $M$. laminarioides, full size and heavily diseased fronds were rarely mature.

Based on the above, the objective of this study was to determine the extent to which endophytic infections affect the reproductive potential of Mazzaella laminarioides by comparing the differences in density of reproductive structures and spore germination rate between infected and non-infected plants. In this context, we tested the hypothesis that a negative effect of the infections should result in a negative relationship between infection level (sensu Correa \& Sánchez 1996) and host maturity. The rationale was that: (1) Pleurocapsa-induced galls could divert nutrients away from the reproductive effort of its host; and (2) if frond survival was reduced, infected fronds should rarely be found fully mature, as they were likely to have been eliminated by wave action.

Fig. 1. Mazzaella laminarioides. (a) Healthy tetrasporic plant with a central mature frond surrounded by smaller immature fronds. Scale bar $=2 \mathrm{~cm}$. (b) Cystocarpic frond infected by Endophyton ramosum (arrowheads indicate dark endophyte patches). Scale bar $=2 \mathrm{~cm}$. (c) Details of endophyte filaments growing in medullar host tissue (arrows). Scale bar $=30 \mu \mathrm{m}$. (d) Immature frond infected by Pleurocapsa sp. (arrowheads indicate tumors). Scale bar $=1 \mathrm{~cm}$. (e) Cross section of a tumor (arrow indicates cyanophyte cells). Scale bar $=300 \mu \mathrm{m}$

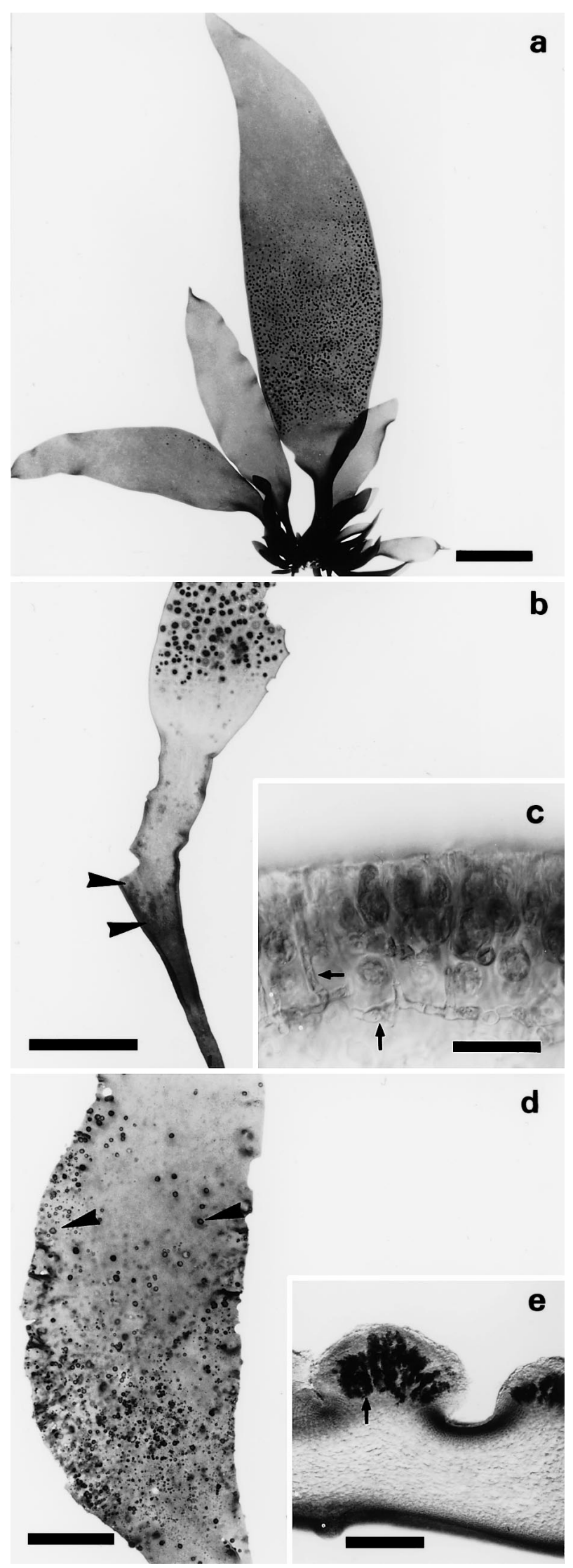




\section{MATERIAL AND METHODS}

Mature fronds $(\mathrm{n}=512)$ of Mazzaella laminarioides were collected in Matanzas ( $\left.33^{\circ} 56^{\prime} \mathrm{S}, 71^{\circ} 53^{\prime} \mathrm{W}\right)$, central Chile, during autumn and winter, the main reproductive period (Santelices \& Martínez 1997). Fronds were collected from 9 different plots of $100 \mathrm{~cm}^{2}$ each, along a $1 \mathrm{~km}$ long rocky beach. Samples included infected and non-infected fronds from cystocarpic and tetrasporic individuals. Infected fronds were sorted according to the presence of infections by Endophyton ramosum, Pleurocapsa sp. or both.

The density of reproductive structures was estimated by counting all the cystocarps or tetrasporangia present in five $1 \mathrm{~cm}^{2}$ quadrats, distributed along a longitudinal transect within each frond (see Santelices \& Martínez 1997). An intra-frond variance in density of reproductive structures was estimated through the coefficient of variation (CV). Simultaneously and in the same fronds, an infection level from 0 (no infection) to 3 (maximum infection severity), as described by Correa \& Sánchez (1996), was determined for each frondpathogen pair. Infection severity was estimated at the base, lamina and apical region of each frond. Thus, for each pathogen, the maximum infection level per frond was 9, and the maximal infection level (summing both pathogens) was 18. Reproductive potential and infection levels were compared using Student's $t$-test, and data were log-transformed when distributions were not normal or when there was a lack of homoscedasticity. Non-parametric tests were used where data could not be normalized.

For statistical purposes, data from autumn and winter were analyzed separately because the overall infection level and the density of reproductive structures were significantly lower in winter (Tables 1 \& 2 respectively). Furthermore, fronds were grouped, regardless their reproductive phase, into infected and non-infected categories, because infection level and density of reproductive structures were not significantly different between cystocarpic and tetrasporic fronds (Tables 1 \& 2).

Germination trials were done using carpospores and tetraspores from fronds infected by one or both pathogens $(\mathrm{n}=44)$, as well as from non-infected fronds $(\mathrm{n}=21)$, all collected from the same site. The protocol for sporulation followed, with minor modifications, that of Santelices \& Martínez (1997). Spores were obtained from 5 circular fragments, $1 \mathrm{~cm}$ in diameter, excised from each frond and incubated in $30 \mathrm{ml}$ filtered seawater for $1 \mathrm{~h}$ in an orbital shaker at $100 \mathrm{rpm}$. Spore suspensions were then distributed into $2 \mathrm{ml}$ wells $(2$ replicates per each suspension). Germinated and nongerminated spores were counted after a $72 \mathrm{~h}$ incubation period.
Table 1. Mazzaella laminarioides. Comparison of mean $(\bar{x})$ infection levels between autumn and winter for the pool of cystocarpic and tetrasporic fronds

\begin{tabular}{|lccccc|}
\hline Source & & Autumn & Winter & $t$ & $\mathrm{p}$ \\
\hline Cystocarpic & $\mathrm{N}$ & 376 & 139 & & \\
and tetrasporic & $\bar{X}$ & 2.72 & 1.80 & 3.88 & $1 \times 10^{-4}$ \\
(pooled) & $\sigma$ & 0.118 & 0.109 & & \\
& & & & & \\
Season & & Cystocarpic & Tetrasporic & $z^{\mathrm{a}}$ & $\mathrm{p}$ \\
\hline Autumn & $\mathrm{N}$ & 195 & 181 & & \\
& $\overline{\mathrm{X}}^{\mathrm{a}}$ & 2.71 & 2.73 & 0.179 & 0.858 \\
Winter & $\sigma$ & 2.28 & 2.29 & & \\
& $\mathrm{~N}$ & 58 & 80 & & \\
& $\overline{\mathrm{X}}^{\mathrm{b}}$ & 1.66 & 1.92 & 1.256 & 0.209 \\
a Normal approximation for Mann-Whitney $U$-test & \\
bog values; original data were not normally distributed \\
\hline
\end{tabular}

\section{RESULTS}

Lengths of infected and non-infected fronds were similar, both in autumn and winter (Table 3 ), indicating that comparisons were done among fronds of similar developmental stage. No significant differences in the density of reproductive structures were found between non-infected and infected fronds, whether they were infected only by Pleurocapsa sp., only by Endophyton ramosum, or by both pathogens simultaneously (Fig. 2). The exception was in fronds infected only by Pleuro-

Table 2. Mazzaella laminarioides. Comparisons of mean densities of reproductive structures $(\bar{X})$

\begin{tabular}{|c|c|c|c|c|c|}
\hline Season & & Cystocarpic & Tetrasporic & $t$ & $\mathrm{p}$ \\
\hline Autumn & $\begin{array}{l}N \\
\bar{X} \\
\sigma\end{array}$ & $\begin{array}{l}195 \\
21.7 \\
13.8\end{array}$ & $\begin{array}{c}181 \\
20.8 \\
10.2\end{array}$ & 0.728 & 0.467 \\
\hline Winter & $\begin{array}{l}\mathrm{N} \\
\bar{X}^{\mathrm{a}} \\
\sigma\end{array}$ & $\begin{array}{c}58 \\
12.2 \\
10.1\end{array}$ & $\begin{array}{c}80 \\
16.2 \\
15.7\end{array}$ & 1.713 & 0.089 \\
\hline $\begin{array}{l}\text { Reproductive } \\
\text { structures }\end{array}$ & & Autumn & Winter & $t$ & $\mathrm{p}$ \\
\hline Cystocarpic & $\begin{array}{l}\mathrm{N} \\
\bar{X} \\
\sigma\end{array}$ & $\begin{array}{l}195 \\
21.7 \\
13.8\end{array}$ & $\begin{array}{c}58 \\
12.2 \\
10.1\end{array}$ & 4.881 & $2 \times 10^{-6}$ \\
\hline Tetrasporic & $\begin{array}{l}\mathrm{N} \\
\bar{X}^{\mathrm{a}} \\
\sigma\end{array}$ & $\begin{array}{c}181 \\
20.8 \\
10.2\end{array}$ & $\begin{array}{c}80 \\
16.2 \\
15.7\end{array}$ & 5.259 & $3 \times 10^{-7}$ \\
\hline $\begin{array}{l}\text { Cystocarpic } \\
\text { and tetrasporic } \\
\text { (pooled) }\end{array}$ & $\begin{array}{l}\mathrm{N} \\
\bar{X}^{\mathrm{a}} \\
\sigma\end{array}$ & $\begin{array}{l}376 \\
21.3 \\
12.2\end{array}$ & $\begin{array}{l}139 \\
14.4 \\
13.7\end{array}$ & 7.195 & $2 \times 10^{-9}$ \\
\hline
\end{tabular}


Table 3. Mazzaella laminarioides. Mean size $(\bar{x})$ comparisons (length in $\mathrm{mm}$ ) between non-infected and infected fronds and between seasons (autumn and winter)

\begin{tabular}{|c|c|c|c|c|c|}
\hline Season & & Non-infected & Infected & $t$ & $\mathrm{p}$ \\
\hline Autumn & $\begin{array}{c}\mathrm{N} \\
\bar{X} \\
\sigma\end{array}$ & $\begin{array}{c}43 \\
129.2 \\
51.4\end{array}$ & $\begin{array}{c}333 \\
122.4 \\
45.7\end{array}$ & 0.90 & 0.368 \\
\hline Winter & $\begin{array}{c}\mathrm{N} \\
\bar{X} \\
\sigma\end{array}$ & $\begin{array}{c}15 \\
107.9 \\
36.9\end{array}$ & $\begin{array}{c}124 \\
127.9 \\
47.2\end{array}$ & 1.58 & 0.117 \\
\hline Condition & & Autumn & Winter & $t$ & $\mathrm{p}$ \\
\hline Non-infected & $\begin{array}{l}\mathrm{N} \\
\bar{X} \\
\sigma\end{array}$ & $\begin{array}{c}43 \\
129.2 \\
51.4\end{array}$ & $\begin{array}{c}15 \\
107.9 \\
36.9\end{array}$ & 1.47 & 0.147 \\
\hline Infected & $\begin{array}{c}\mathrm{N} \\
\bar{X} \\
\sigma\end{array}$ & $\begin{array}{c}333 \\
122.4 \\
45.7\end{array}$ & $\begin{array}{c}124 \\
127.9 \\
47.2\end{array}$ & 1.04 & 0.299 \\
\hline
\end{tabular}

capsa sp. in autumn, where infected thalli had an even higher density of reproductive structures than their non-infected counterparts. Finally, the CV calculated for the density of reproductive structures was significantly different between infected and non-infected fronds only in autumn, where a significantly lower CV was observed in infected fronds (Table 4).

Since these results were obtained by including all infected fronds, regardless of the level of infection, a new set of comparisons was done by eliminating from the calculations those fronds with low levels of infection, those which may be considered non-infected from a structural and physiological perspective. However, even though only heavily infected fronds (i.e. infection level $\geq 2$ ) were considered, no significant difference in the densities of their reproductive structures was found when compared to non-infected thalli (results not shown).

The effect of the infections on carpospore germination was statistically significant (Kruskal-Wallis

Table 4. Mazzaella laminarioides. Comparisons of mean variability $(\mathrm{CV}$, coefficient of variation) in the density of reproductive structures between non-infected and infected fronds

\begin{tabular}{|clcccc|}
\hline Season & & Non-infected & $\begin{array}{c}\text { Infected } \\
\text { (single or } \\
\text { combined) }\end{array}$ & $t$ & $\mathrm{p}$ \\
\hline Autumn & $\mathrm{N}$ & 43 & 333 & & \\
& $\mathrm{CV}$ & 177.6 & 75.3 & 9.763 & $1.4 \times 10^{-14}$ \\
& $\sigma$ & 134.3 & 49.3 & & \\
Winter & $\mathrm{N}$ & 15 & 124 & & 0.421 \\
& $\mathrm{CV}$ & 123.3 & 109.4 & 0.806 & 0.4 \\
& $\sigma$ & 78.1 & 61.4 & & \\
\hline
\end{tabular}

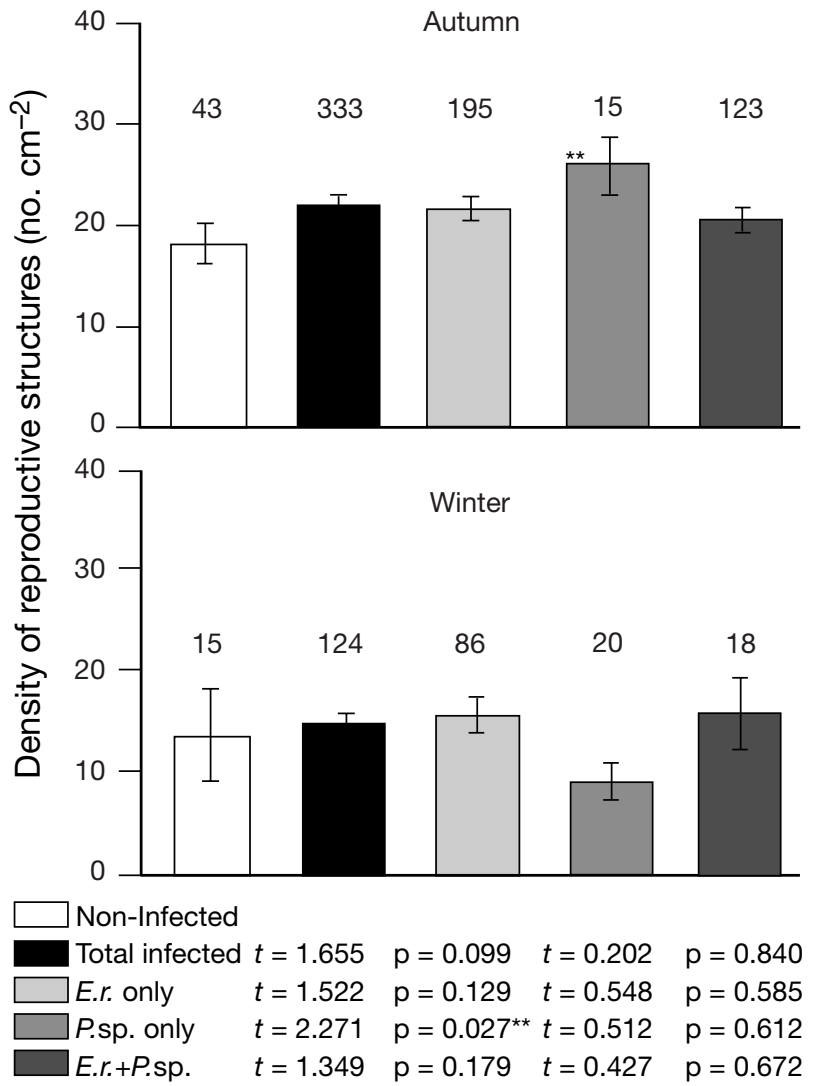

Fig. 2. Mazzaella laminarioides. Comparisons of mean densities of reproductive structures between non-infected and infected fronds. $t$-values and $\mathrm{p}$-values correspond respectively to $t$-tests between non-infected fronds and total of infected, infected only by Endophyton ramosum (E.r. only), only by Pleurocapsa sp. (P.sp. only), or by both pathogens simultaneously (E.r. + P.sp.). Values above each bar correspond to the number of analysed fronds in each category. Vertical bars are standard deviation

ANOVA $[K W]=15.9, p=0.002$ ). Carpospores released from fronds infected only by Pleurocapsa sp. or by both Pleurocapsa sp. and Endophyton ramosum had germination rates of $6 \%$ or lower (Table 5). Conversely, carpospores released from non-infected fronds or infected only by E. ramosum had germination rates of $17 \%$ or higher (Table 5). Tetraspores, on the other hand, showed no significant differences in germination rates $(\mathrm{KW}=2.8, \mathrm{p}=0.420)$ whether they came from infected or non-infected fronds (Table 5).

\section{DISCUSSION}

The objective of this study was to estimate the effect of endophytic infections on the reproductive potential of Mazzaella laminarioides. The results on frond maturity suggest that infections by Pleurocapsa sp. and 
Table 5. Mazzaella laminarioides. Germination rates (\%) in spores derived from non-infected and infected fronds

\begin{tabular}{|lrrrrrrr|}
\hline \multirow{2}{*}{ Treatment } & \multicolumn{3}{c}{ Cystocarpic fronds } & \multicolumn{3}{c|}{ Tetrasporic fronds } \\
& $\bar{x}$ & SE & N & $\bar{x}$ & SE & N \\
\hline Endophyton ramosum & 27.2 & 8.8 & 10 & 11.5 & 6.7 & 7 \\
Pleurocapsa sp. & 0.0 & 0.0 & 10 & 5.6 & 4.8 & 8 \\
Endophyton ramosum + Pleurocapsa sp. & 5.5 & 5.5 & 6 & 8.5 & 5.6 & 3 \\
Non-infected plants & 17.6 & 7.5 & 10 & 14.3 & 5.8 & 11 \\
& & & & & & \\
\hline
\end{tabular}

Endophyton ramosum have no negative effect on the production of reproductive structures in the host. In fact, the only case of significant differences between infected (by Pleurocapsa sp.) and non-infected fronds revealed that infected thalli had higher density of reproductive structures. Furthermore, in terms of variability of the distribution of reproductive structures within the fronds, the results showed no differences between infected and non-infected thalli in winter, whereas a significantly lower variability in infected fronds was found in autumn. However, these differences should be treated with caution as the sample sizes were quite different (see Table 4). In addition, infected fronds were statistically similar in size to noninfected thalli, which indicates that they are not eliminated before reaching full size and maturity, as suggested by previous work (Buschmann et al. 1997). Thus, and contrary to our hypothesis, it seems that infected fronds of $M$. laminarioides grow and mature at least as well as their non-infected counterparts.

From a physiological point of view, this lack of negative effect of the endophytes is consistent with previous observations indicating that red algal hosts were able to fix enough carbon to meet their own metabolic requirements as well as those of their parasites (Kremer 1983). In our study, it has to be considered that both pathogens infecting Mazzaella laminarioides are pigmented and therefore independent of the carbohydrates from the host. In fact, they are able to grow separately from their host (Correa et al. 1993, 1994) and, so far, no ultrastructural evidence has been found to support or suggest carbon transfer between the pathogens and their host (Correa et al. 1993, 1994); this is why they have been described as endophytes and not parasites (see Correa 1994). The apparent physiological (i.e. nutritional) independence of the 2 pathogens could lead to a relationship of no metabolic cost to the host, and therefore, these pathogenes represent no detriment to the reproductive process in M. laminarioides.

However, the present work suggests that although the number of reproductive structures may not be reduced by the infections, these may have a negative impact on spore quality. This effect was clear and sig- nificant in cystocarpic fronds attacked by the cyanobacterium, where spores displayed a lower level of germination than spores from non-infected thalli. These results suggest that there may be some developmental processes within the carpospores that appear to be affected in such a way that the effect is expressed during the key step of germination. Although at present no evidence has been found to explain why carpospores, and not tetraspores, are negatively affected by Pleurocapsa infections, we suggest that the intimate cellular events taking place during carpospore formation may be involved. Indeed, whereas a tetraspore is the result of a single meiotic event, carpospores result after many successive mitoses of a single carpogonial cell (Bold \& Wynne 1985). This repetitive process may lead to some kind of 'metabolic exhaust' of carpogonial cells developing in the cortical tissue, which is simultaneously involved in highenergy expenditure due to the hyperplasia and hypertrophy affecting the vegetative cells (Correa et al. 1993). Thus, although the formation of carpospores may not be fully interrupted, energy deviation into the formation of tumors may indirectly result in lower quality carpospores.

The differential responses, in terms of spore quality, determined by the 2 pathogens seem to be the result of quite different patterns of infection within the fronds. Pleurocapsa-induced galls usually affect the whole lamina (Correa et al. 1993), whereas the chlorophycean Endophyton ramosum concentrates mostly in the basal portions of the fronds (Correa et al. 1994) where reproductive structures do not normally develop (Fig. 1). Therefore, if there is a negative effect on 1 or more processes during spore maturation, while they are still in the parental frond, it seems likely that Pleurocapsa sp., and not E. ramosum, would be responsible. In addition, this negative effect could be linked to the density of reproductive structures that was found to be significantly higher in fronds infected by Pleurocapsa sp.: with a higher density of reproductive structures, a lower quality of spores was produced.

In terrestrial plant-pathogen systems empirical data indicate that host fitness can be affected by either debilitating the host or reducing seed quality and quantity. The intensity of this effect ranges from no reduction in host fitness to castrating or killing the host before reproduction (for review, see Clay \& Kover 1996). The interaction between Mazzaella laminarioides and its endophytes seems to fit better within the old belief that long-term co-evolution would tend to reduce the virulence of the parasites, thus resulting in mild negative effects on the hosts (Toft \& Karter 1990). 
However, some caution is advised until additional experimental evidence is made available, as spore quality of $M$. laminarioides was affected by the infections. This could lead to lower recruitment coming from infected plants as compared to that from noninfected fronds, a phenomenon which is by definition a reduction in host fitness.

A differential and negative effect of a pathogen on one of the life history stages of its host may have profound effects at the population level. In the case of Mazzaella laminarioides, as the gametophytic phase seems to be the only one affected by the infections, a population of this host could display, at least locally, some kind of disequilibrium in the haplo/diploid ratio. It has already been suggested that such an effect, at the population level, can explain the gametophytic dominance in natural populations of the red alga Chondrus crispus (McLachlan 1991). Indeed, in this host species, the filamentous green alga Acrochaete operculata, which produces a disease similar to that caused by Endophyton ramosum in M. laminarioides, infects only the sporophytic blades (Correa \& McLachlan 1991). In $M$. laminarioides, both reproductive phases are infected (Correa et al. 1993, Sánchez et al. 1996) but, as in C. crispus, the gametophytes are generally more abundant on the rocky shores (Luxoro \& Santelices 1989). Thus, comparative assessment of the abundance of both reproductive phases in highly infected and not infected zones, currently underway, should shed some additional light on the still poorly understood interactions between $M$. laminarioides and its algal endophytes.

Acknowledgements. S.F. was partially supported by a French Lavoisier fellowship. The investigation was funded by the research grant FONDECYT \#1990145 to J.A.C., FONDECYT \#1990235 to E.A.M., the Italian-Chilean cooperation program CICS-EULA-Genova-PUCCh, and the ECOS-CONICYT cooperation program with France. We thank V. Flores for her help with photography.

\section{LITERATURE CITED}

Andrews JH (1976) The pathology of marine algae. Biol Rev 51:211-253

Andrews JH, Goff LJ (1984) Pathology. In: Littler MM, Littler DS (eds) Handbook of phycological methods. Ecological field methods: Macroalgae. Cambridge University Press, Cambridge, p 573-591

Apt KE (1984) Effects of the symbiotic red alga Hypneocolax stellaris on its host Hypnea musciformis (Hypneaceae, Gigartinales). J Phycol 20:148-150

Bold HC, Wynne MJ (1985) Introduction to the algae, 2nd edn. Prentice-Hall Inc, Englewood Cliffs, NJ
Buschmann A, Correa JA, Beltran J, Retamales C (1997) Determinants of disease expression and survival of infected individual fronds in wild populations of Mazzaella laminarioides (Rhodophyta) in central and southern Chile. Mar Ecol Prog Ser 154:269-280

Clay K, Kover PX (1996) The Red Queen Hypothesis and plant/pathogen interactions. Annu Rev Phytopathol 34: $29-50$

Correa JA (1994) Infections by pigmented algal endophytes: misuse of concepts and terminology. Rev Chil Hist Nat $67: 4-8$

Correa JA (1997) Infectious diseases of marine algae: current knowledge and approaches. In: Round FE, Chapman DJ (eds) Progress in phycologycal research, Vol 12. Biopress Ltd, Bristol, p 149-180

Correa JA, McLachlan JL (1991) Endophytic algae of Chondrus crispus (Rhodophyta). III. Host specificity. J Phycol $27: 448-459$

Correa JA, Sánchez P (1996) Ecological aspects of algal infectious diseases. Hydrobiologia 326/327:89-95

Correa JA, Flores V, Sánchez P (1993) Deformative disease in Iridaea laminarioides (Rhodophyta): gall development associated with an endophytic cyanobacterium. J Phycol 29: 853-860

Correa JA, Flores V, Garrido J (1994) Green patch disease in Iridaea laminarioides (Rhodophyta) caused by Endophyton sp. (Chlorophyta). Dis Aquat Org 19:203-213

Correa JA, Buschmann A, Retamales C, Beltrán J (1997) Infectious diseases of Mazzaella laminarioides (Rhodophyta): changes in infection prevalence and disease expression associated with season, locality, and within-site location. J Phycol 33:344-352

Kremer BP (1983) Carbon economy and nutrition of the alloparasitic red alga Harveyella mirabilis. Mar Biol 76:231-239

Luxoro C, Santelices B (1989) Additional evidence for ecological differences among isomorphic reproductive phases of Iridaea laminarioides (Rhodophyta: Gigartinales). J Phycol 25:206-212

McLachlan JL (1991) Chondrus crispus (Irish moss), an ecologically important and commercially valuable species of red seaweed of the North Atlantic Ocean. In: Mauchline J, Nemoto T (eds) Marine biology. Its accomplishments and future prospects. Hokusen-sha Publ. Co., Tokyo, p 221-237

Müller DG, Frenzer K (1993) Virus infections in three marine brown algae: Feldmania irregularis, F. simplex and Ectocarpus siliculosus. Hydrobiologia 260/261:37-44

Müller DG, Stache B, Lanka S (1990) A virus infection in the marine brown algae Ectocarpus siliculosus (Phaeophyta). Bot Acta 103:72-82

Parodi ER, Müller DG (1994) Field and culture studies on virus infections in Hincksia hincksiae and Ectocarpus fasciculatus (Ectocarpales, Phaeophyceae). Eur J Phycol 29: 113-117

Sánchez PA, Correa JA, García-Reina G (1996) Host-specificity of Endophyton ramosum (Chlorophyta), the causative agent of the green patch disease in Mazzaella laminarioides (Rhodophyta). Eur J Phycol 31:173-179

Santelices B, Martínez E (1997) Hierarchical analysis of reproductive potential in Mazzaella laminarioides (Gigartinaceae, Rhodophyta). Phycologia 36:195-207

Toft CA, Karter AJ (1990) Parasite-host coevolution. TREE 5: 326-329

Submitted: March 2, 2000; Accepted: May 5, 2000

Proofs received from author(s): August 9, 2000 